\title{
PENGARUH MODEL PEMBELAJARAN KOLABORATIF DITINJAU DARI MOTIVASI BERPRESTASI TERHADAP HASIL BELAJAR IPA
}

\author{
I Dewa Ayu Yoni Dian Anggreni ${ }^{1}$, I Gede Margunayasa ${ }^{2}$, Ni Nyoman \\ Kusmariyatni $^{3}$
1,2,3 Jurusan Pendidikan Guru Sekolah Dasar, FIP Universitas Pendidikan Ganesha Singaraja, Indonesia e-mail: yonianggreni@yahoo.com1, igede.margunayasa@undiksha.ac.id2, nyoman.kusmariyatni@undiksha.ac.id3

\begin{abstract}
ABSTRAK
Penelitian ini bertujuan mengetahui perbedaan yang signifikan model pembelajaran kolaboratif terhadap hasil belajar IPA sebelum dan setelah mengontrol motivasi berprestasi siswa. Jenis penelitian ini adalah peneltian kuasi eksperimen dengan rancangan non-equivalent post-test only control group design. Populasi pada penelitian ini adalah siswa kelas V SD di Gugus III Kecamatan Sawan Kabupaten Buleleng Tahun Pelajaran 2017/2018 yang berjumlah 163 siswa dan sampel diambil dengan teknik random sampling. Data motivasi berprestasi dikumpulkan dengan instrumen berupa kuesioner dan data hasil belajar IPA dikumpulkan dengan instrumen tes pilihan ganda. Teknik analisis yang digunakan adalah uji-t sampel independent dan ANAKOVA satu jalur. Hasil penelitian menunjukkan bahwa terdapat perbedaan yang signifikan model pembelajaran kolaboratif terhadap hasil belajar IPA sebelum mengontrol motivasi berprestasi siswa (thitung $=6,583$ dan signifikansi $0,000<0,05$ ) dan setelah mengontrol motivasi berprestasi siswa (Fhitung $=76,791$ dan signifikansi $0,000<0,05$ ). Dari rata-rata hitung, diketahui bahwa rata-rata hasil belajar IPA kelompok eksperimen lebih besar dibandingkan rata-rata hasil belajar IPA kelompok kontrol $(22,47$ > 16,00). Jadi model pembelajaran kolaboratif ditinjau dari motivasi berprestasi siswa berpengaruh terhadap hasil belajar IPA siswa kelas V SD di Gugus III Kecamatan Sawan Kabupaten Buleleng Tahun Pelajaran 2017/2018.
\end{abstract}

Kata kunci: hasil belajar IPA, model pembelajaran kolaboratif, motivasi berprestasi.

\begin{abstract}
The aim of this research was to know the significant difference of collaborative learning model to science learning result before and after controlling the student achievement motivation. The type of this research was quasi experimental research with non-equivalent post-test only control group design. The population of this research was the 163 students of fifth grade of elementary school in Cluster III Sawan Sub-District of Buleleng Regency in Academic Year 2017/2018 and The sampel was taken by using random sampling thenique. The achievement motivation data were collected by using questionnaires and the science data were collected by using multiple choice test instruments. The analysis technique used was t-test of independent sample and ANAKOVA one lane. The result of the research showed that there is a significant difference of collaborative learning model to the science learning result before controlling the students achievement motivation (tcound $=6,583$ and significance $0,000<0,05$ ) and after controlling the students achievement (Fcount $=76,791$ and significance $0,000<0,05$ ). Moreover, it is known that the average science learning result experimental group is higher than average science learning result control group $(22,47>16,00)$. This means that, the collaborative learning model that is seen from achievement motivation of students influenced the science learning result of fifth grade of elementary students in Cluster III Sawan Sub-District Buleleng Regency in the Academy Year 2017/2018.
\end{abstract}

Keywords: achievement motivation, collaborative learning model, science learning result. 


\section{Pendahuluan}

Pendidikan merupakan hal yang sangat penting, karena pendidikan berperan sebagai salah satu faktor yang memengaruhi kualitas atau mutu Sumber Daya Manusia (SDM). Kosasih dan Sumarna (2013) menyatakan bahwa saat ini keunggulan bangsa tidak lagi ditandai dengan kepemilikan Sumber Daya Alam (SDA) yang melimpah. Keunggulan bangsa dapat dilihat dari kepemilikan SDM yang berkualitas, sehingga mampu mengolah SDA yang ada di sekitarnya. Salah satu cara meningkatkan kualitas SDM adalah dengan meningkatkan kualitas di bidang pendidikan. Melalui proses pendidikan kepribadian dan kecerdasan intelektual seseorang semakin berkembang.

Syaefudin (2009:6) menyatakan bahwa "pendidikan merupakan upaya yang dapat mempercepat pengembangan potensi manusia untuk mampu mengembangkan tugas yang dibebankan kepadanya, karena hanya manusia yang dapat dididik dan mendidik". Proses dididik dan mendidik menjadi pokok pembahasan dalam sebuah pendidikan, karena dalam program pendidikan peserta didik tidak hanya harus mampu dididik, tetapi juga diarahkan untuk mendidik, baik mendidik diri sendiri, teman sebaya, dan orang-orang di lingkungan sekitar. UU Nomor 20 Tahun 2003 Pasal 1 tentang Sistem Pendidikan Nasional berbunyi, "pendidikan adalah usaha sadar terencana untuk mewujudkan suasana belajar dan proses pembelajaran agar peserta didik secara aktif mengembangkan potensi dirinya untuk memiliki kekuatan spiritual, keagamaan, pengendalian diri, kepribadian, kecerdasan, akhlaq mulai serta keterampilan yang diperlukan dirinya, masyarakat, dan bangsanya. Berdasarkan pendapat tersebut dapat disintesis bahwa pendidikan merupakan usaha sadar terencana untuk memanusiakan manusia, diwujudkan melalui pengembangan potensi diri meliputi, karakter, pikiran, dan jasmani melalui proses dididik dan mendidik sehingga berguna bagi individu itu sendiri dan masyarakat.

Pendidikan juga memiliki tujuan bagi penyelenggara dan pelaksana pendidikan itu sendiri. Tujuan pendidikan dapat memberikan arah bagi pendidikan yang sedang dilaksanakan. Secara umum tujuan pendidikan telah diatur dalam UU Nomor 20 Tahun 2003 tentang Tujuan Pendidikan Nasional Pasal 3 yang menyatakan "pendidikan nasional berfungsi untuk mengembangkan kemampuan dan membentuk watak serta peradaban bangsa yang bermartabat dalam rangka mencerdaskan kehidupan bangsa, bertujuan mengembangkan potensi peserta didik agar menjadi manusia yang beriman dan bertaqwa kepada Tuhan Yang Maha Esa, berahklak mulia, sehat, berilmu, cakap, kreatif, mandiri, dan menjadi warga Negara yang demokratis serta bertanggung jawab".

Mewujudkan tujuan pendidikan yang telah diatur dalam UU tidak semudah membalikan telapak tangan, banyak proses yang harus dilalui dan terwujud tidaknya tujuan tersebut bergantung pada kualitas setiap proses pendidikan yang dilaksanakan. Salah satu proses yang harus dilalui seseorang adalah jenjang Sekolah Dasar (SD). Perbaikan kualitas pendidikan terutama pada jenjang SD terus dilakukan oleh pemerintah dan instansi terkait, dibuktikan dengan adanya pembaharuan dibidang kurikulum, pelatihan yang diberikan kepada tenaga pendidik, penggunaan pendekatan, model, strategi, metode, teknik, dan taktik yang mulai disesuaikan dengan karakteristik peserta didik serta perbaikan dalam bidang sarana prasarana. Perbaikan kualitas pendidikan dilaksanakan dalam berbagai disiplin ilmu pada jenjang SD, salah satu disiplin ilmu tersebut adalah IImu Pengetahuan Alam (IPA).

Menurut Samatowa (2010:3) "ilmu pengetahuan alam merupakan terjemahan kata-kata dalam bahasa Inggris yaitu natural science, artinya IImu Pengetahuan Alam (IPA)". Sains atau sering disebut dengan IImu Pengetahuan Alam (IPA) merupakan salah satu mata pelajaran wajib di jenjang SD. "IPA adalah salah satu mata pelajaran yang berbasis ilmu pengetahuan dan bersumber dari alam. IPA berupaya membangkitkan minat manusia untuk meningkatkan kecerdasan dan pemahaman mengenai alam dan seisinya" (Saputra, dkk, 2017:171). Sains atau IPA juga diartikan sebagai usaha manusia dalam memahami alam semesta melalui pengamatan yang tepat sasaran, serta menggunakan prosedur dan dijelaskan dengan penalaran sehingga memeroleh suatu simpulan. Lebih lanjut, Susanto (2013) menyatakan IPA adalah usaha manusia dalam memahami alam semesta melalui 
pengamatan yang tepat sasaran, serta menggunakan prosedur dan dijelaskan dengan penalaran sehingga memeroleh suatu simpulan. Jadi dari pendapat ahli yang mengemukakan tentang pengertian sains atau IPA dapat disintesis bahwa IPA adalah ilmu yang memelajari tentang peristiwa atau gejala-gejala alam dan disusun secara sistematis menggunakan metode ilmiah sehingga memeroleh suatu simpulan.

Manfaat pembelajaran IPA dapat dirasakan oleh peserta didik ketika pembelajaran tersebut tidak monoton, mampu menarik perhatian, dan menyenangkan. Peserta didik akan menikmati pembelajaran yang dilaksanakan dan secara simultan terjadi peningkatan terhadap hasil belajar. Menurut Kosasih dan Sumarna (2013:38) "hasil belajar merupakan kompetensi yang dimiliki peserta didik setelah mengalami proses belajar yang ditunjukan dengan adanya perubahan pada ranah kognitif, afektif, dan psikomotor". Senada dengan pendapat tersebut Susanto (2013) juga menyatakan bahwa hasil belajar merupakan perubahan-perubahan yang dialami dalam diri siswa, baik menyangkut aspek kognitif, afektif, dan psikomotor setelah melalui kegiatan belajar. Dari pendapat ahli tentang pengertian hasil belajar, dapat disintesis bahwa hasil belajar adalah hasil yang diperoleh siswa dari pengalaman belajarnya berupa perubahan tingkah laku pada ranah kognitif, afektif, dan psikomotor. Pada penelitian ini hasil belajar yang diukur adalah hasil belajar pada ranah kognitif.

Pada pelaksanaan observasi, wawancara, dan studi dokumentasi di Gugus III Kecamatan Sawan Kabupaten Buleleng yang terdiri atas tujuh SD dan berlangsung dari tanggal 08 sampai 10 Januari 2018, diperoleh beberapa informasi dan data tentang pelaksanaan pembelajaran di kelas $\mathrm{V}$ khususnya pada mata pelajaran IPA. Berdasarkan hasil observasi, kegiatan siswa selama proses pembelajaran berlangsung cenderung monoton. Siswa diminta untuk membaca buku tentang materi yang diajarkan, mengemukakan apa yang dibaca, mengerjakan tugas, dan membahas tugas tersebut. Ketika siswa mengerjakan tugas, siswa kurang melakukan interaksi melalui proses kerjasama dengan teman sekelasnya. Siswa memilih untuk mengerjakan sendiri atau bersama teman sebangku. Jika tidak menemukan jawaban, siswa memilih diam dan menunggu guru membahas tugas tersebut. Siswa hanya menjawab apa yang mampu dijawab tanpa mencoba melakukan kolaborasi dengan teman lainnya. Suasana kelas menjadi kurang kondusif dan kesempatan tersebut dimanfaatkan oleh siswa yang tidak serius belajar untuk bercanda dan membicarakan hal di luar pelajaran.

Berdasarkan hasil wawancara bersama guru kelas $\mathrm{V}$, diketahui bahwa metode pembelajaran yang sering digunakan guru adalah metode ceramah, tanya jawab, dan diskusi. Metode diskusi yang dilakukan biasanya metode diskusi bersama teman sebangku atau bersama kelompok. Pembelajaran dengan sistem kelompok sudah dilaksanakan pada beberapa pertemuan, namun saat pembelajaran berlangsung siswa sulit diatur, beberapa anggota kelompok bercanda dalam diskusi, dan hanya 1 atau 2 orang yang aktif melakukan diskusi dan mengerjakan tugas, sehingga proses pembelajaran menjadi kurang efektif. Pengetahuan guru tentang penggunaan model pembelajaran juga masih kurang, khusunya model pembelajaran kolaboratif yang dapat membantu guru mengatasi masalah yang berhubungan dengan sistem kelompok. Faktor-faktor lain yang memengaruhi hasil belajar juga kurang diperhatikan, seperti pengaruh motivasi berprestasi siswa. Guru belum pernah mengukur tingkat motivasi berprestasi siswa, sehingga belum mengetahui seberapa besar pengaruh motivasi berprestasi terhadap hasil belajar siswa.

Pada studi dokumentasi yang dilaksanakan, nilai UAS (Ulangan Akhir Semester) mata pelajaran IPA siswa kelas V semester I diketahui bahwa jumlah siswa yang mencapai KKM sebanyak 58 siswa dan yang belum mencapai KKM sebanyak 105 siswa dari total 163 siswa. Jika dilihat dari rata-rata persentase pencapaian KKM, sebanyak $63,28 \%$ belum mencapai $\mathrm{KKM}$ dan hanya $36,72 \%$ yang mencapai KKM. Jadi dari data tersebut dapat disimpulkan bahwa hasil belajar IPA siswa masih rendah.

Diperlukan kerjasama antar pihak-pihak terkait seperti, guru, siswa, kepala sekolah, dan instansi terkait lainnya untuk menyelesaikan masalah tersebut. Salah satu cara yang bisa ditempuh adalah dengan menciptakan pembelajaran yang berpusat pada siswa (student centered). Dapat dilakukan dengan menerapkan model pembelajaran yang sesuai dengan 
karakteristik siswa dan permasalahan yang dialami. Salah satunya adalah penggunaan model pembelajaran kolaboratif. Menurut Sato (2014:21) terdapat empat alasan model pembelajaran kolaboratif cocok diterapkan dalam pembelajaran yaitu, "(1) pembelajaran kolaboratif merupakan esensi pembelajaran, (2) untuk mewujudkan hak belajar setiap siswa tanpa terkecuali tidak ada metode selain saling belajar sesama siswa melalui pembelajaran kolaboratif, (3) menunjukkan bahwa pembelajaran kolaboratif kelompok kecil merupakan sarana memperbaiki kemampuan akademis siswa yang rendah, dan (4) pembelajaran kolaboratif juga bisa menjamin siswa dengan kemampuan akademis tinggi lebih baik lagi. Akan tetapi, untuk itu ada persyaratan yang harus dipenuhi, pembelajaran kolaboratif harus pula mencakup tantangan menuju materi yang lebih tinggi levelnya, yang disebut dengan 'materi lompatan' (jumping)".

Kolaboratif berasal dari bahasa Latin collaborate yang berarti kerjasama dan sering diistilahkan sebagai co-labor yang memiliki arti kerjasama (Barkley, dkk, 2014). Dewi, dkk (2016:30) menyatakan model pembelajaran kolaboratif merupakan "model pembelajaran yang dapat melatih siswa bekerjasama dengan temannya untuk menemukan materi pembelajaran". "Collaborative learning adalah proses belajar kelompok yang setiap anggota menyumbangkan informasi, pengalaman, ide, sikap, pendapat, kemampuan, dan keterampilan yang dimilikinya, untuk secara bersama-sama meningkatkan pemahaman seluruh anggota" Sudarman (2008:94). Pembelajaran kolaboratif dengan komunikasi interaktif dibentuk oleh dua hubungan yaitu saling mendengarkan dan saling belajar (Sato, 2014). Berdasarkan pendapat ahli tersebut dapat disintesis model pembelajaran kolaboratif adalah suatu model pembelajaran yang berpusat pada siswa, dengan mengajak siswa bekerja bersama-sama atau menciptakan hubungan saling mendengarkan dan saling belajar dalam kelompok kecil untuk berani menyumbangkan pendapat, pengalaman, ide, dan keterampilan yang dimiliki agar dapat meningkatkan pemahaman seluruh anggota kelompok serta mencapai tujuan yang telah ditetapkan.

Solusi dengan menerapkan model pembelajaran kolaboratif didukung oleh penelitian yang dilakukan oleh Primadiati dan Djukri (2017) yaitu model collaborative learning memberikan pengaruh terhadap peningkatan hasil belajar dan motivasi siswa pada mata pelajaran IPA. Penelitian yang dilakukan oleh Santoso (2013) menyatakan terdapat perbedaan yang signifikan model pembelajaran kolaboratif dibandingkan metode ceramah. Penelitian serupa dilakukan oleh Marhamah, dkk (2017) yang menunjukkan terdapat pengaruh positif hasil belajar siswa setelah menggunakan model pembelajaran kolaboratif berbasis lesson study learning community. Berdasarkan ketiga penelitian tersebut model pembelajaran kolaboratif dapat meningkatkan hasil belajar siswa.

Selain penggunaan model pembelajaran yang tepat, terdapat berbagai faktor yang juga memengaruhi hasil belajar IPA siswa. Menurut Musfiqon (2012:8) "hasil belajar siswa dipengaruhi oleh dua faktor utama, yakni faktor dalam diri siswa (internal factor) dan faktor yang datang dari luar diri siswa atau faktor lingkungan (external factor)". Salah satu faktor dari dalam diri siswa adalah motivasi berprestasi. Hal tersebut diperkuat oleh pendapat Djaali (2008:110) menyatakan bahwa "motivasi berprestasi merupakan salah satu faktor yang ikut menentukan keberhasilan dalam belajar". Sofyan (2014:72) menyatakan bahwa "motif berprestasi adalah suatu dorongan dari dalam diri untuk selalu meraih prestasi". Senada dengan pendapat tersebut Firmansyah (2009:32) mendefinisikan motivasi berprestasi sebagai "motif yang mendorong seseorang berpacu dengan keunggulan orang lain dan keunggulan diri sendiri".

Djaali (2008:103) juga mengungkapkan tentang pengertian motivasi berprestasi, ia mengemukakan bahwa motivasi berprestasi merupakan "kondisi fisiologi dan psikologis (kebutuhan untuk berprestasi) yang terdapat di dalam diri siswa yang mendorong untuk melalukan aktivitas tertentu guna mencapai tujuan tertentu". Dari pendapat ahli tersebut dapat disintesis motivasi berprestasi adalah motif atau dorongan dalam diri yang mengarahkan tingkah laku siswa sehingga menyebabkan peningkatan aktivitas dalam kemampuan, guna berpacu dengan keunggulan orang lain dan diri sendiri untuk mendapatkan keberhasilan dalam mencapai tujuan. Motivasi berprestasi memiliki peran yang kuat dalam menunjang proses pembelajaran oleh karena itu perlu dilakukan 
pengontrolan terhadap motivasi berprestasi untuk mengetahui pengaruh model pembelajaran kolaboratif terhadap hasil belajar IPA. Jadi pada penelitian ini motivasi berprestasi didudukan sebagai variabel kontrol bukan didudukan sebagai variabel moderator.

Berdasarkan uraian tersebut, dilakukan penelitian yang bertujuan mengetahui (1) perbedaan yang signifikan hasil belajar IPA antara siswa yang dibelajarkan dengan model pembelajaran kolaboratif dan siswa yang dibelajarkan dengan pembelajaran konvensional pada siswa kelas V SD di Gugus III Kecamatan Sawan Kabupaten Buleleng Tahun Pelajaran 2017/2018 dan (2) perbedaan yang signifikan hasil belajar IPA antara siswa yang dibelajarkan dengan model pembelajaran kolaboratif dan siswa yang dibelajarkan dengan pembelajaran konvensional setelah mengontrol motivasi berprestasi pada siswa kelas V SD di Gugus III Kecamatan Sawan Kabupaten Buleleng Tahun Pelajaran 2017/2018.

\section{Metode}

Jenis penelitian ini adalah eksperimen semu (quasi experiment), disebut demikian karena tidak semua variabel yang muncul dapat dikontrol secara ketat. Desain yang digunakan dalam penelitian ini adalah non-equivalen post-test only control group design karena tidak mungkin mengubah kelas-kelas atau struktur yang sudah ada. Populasi dalam penelitian ini adalah siswa kelas V SD di Gugus III Kecamatan Sawan Kabupaten Buleleng Tahun Pelajaran 2017/2018 yang berjumlah 163 siswa. Selanjutnya dari tujuh kelas yang ada di Gugus III dilakukan uji kesetaraan dan hasilnya ketujuh kelas tersebut setara. Pemilihan sampel menggunakan teknik random sampling atau pengundian tanpa pengembalian sebanyak dua kali, yaitu menentukan sampel serta menentukan kelompok eksperimen dan kontrol. Jadi dari hasil pengundian, SD Negeri 2 Menyali yang berjumlah 32 siswa terpilih menjadi kelompok eksperimen dan SD Negeri 1 Jagaraga yang berjumlah 33 siswa terpilih menjadi kelompok kontrol.

Penelitian ini melibatkan tiga variabel, yaitu variabel bebas, variabel terikat, dan variabel kontrol. Bertindak sebagai variabel bebas adalah model pembelajaran kolaboratif. Hasil belajar bertindak sebagai variabel terikat. Motivasi berprestasi bertindak sebagai variabel kontrol. Model pembelajaran kolaboratif diterapkan pada kelompok eksperimen dan kelompok kontrol menerapkan pembelajaran kovensional, artinya pembelajaran yang sudah biasa dlaksanakan di kelas tersebut dan tidak menerapkan model pembelajaran kolaboratif. Dilaksanakan sebanyak delapan kali, yaitu tujuh kali pembelajaran dan satu kali post-test pada pertemuan kedelapan. Sebelum memasuki delapan kali pertemuan, terlebih dahulu dilakukan pengukuran terhadap motivasi berprestasi siswa.

Terdapat dua jenis data yang dikumpulkan dalam penelitian ini yaitu. Pertama data motivasi berprestasi yang diukur menggunakan instrumen berupa kuesioner. Terdapat lima aspek yang diukur dalam motivasi berprestasi yaitu: (1) upaya mencapai keberhasilan, (2) berorientasi pada keberhasilan, (3) inovatif, (4) bertanggungjawab, dan (5) mengantisipasi kegagalan (Suarni, 2004). Kedua data hasil belajar IPA diukur menggunakan tes hasil belajar berupa tes pilihan ganda. Hasil belajar IPA yang diukur adalah pada domain kognitif yang didasarkan pada Taksonomi Bloom revisi Anderson dan Krathwol (dalam Office for Development, 2006) yaitu: memahami (C2), menerapkan (C3), menganalisis (C4), dan mengevaluasi (C5). Pemilihan masing-masing tingkatan disesuaikan dengan rancangan SK (Standar Kompetensi), KD (Kompetensi Dasar), dan indikator.

Sebelum digunakan dalam penelitian, perlu dilakukan uji coba terhadap instrumen kuesioner motivasi berprestasi dan hasil belajar IPA. Uji coba instrumen kuesioner motivasi berprestasi dilakukan pada siswa kelas V di Gugus III yang tidak terpilih sebagai sampel, yaitu siswa SD Negeri 2 Sawan, SD Negeri 3 Sawan, dan SD Negeri 3 Menyali yang berjumlah 53 siswa. Selanjutnya diakukan uji validitas yang terdiri atas uji validitas isi dan uji validitas butir serta uji reliabilitas. Dari 40 butir pernyataan kuesioner motivasi berprestasi yang disiapkan dipilih 30 butir yang digunakan dalam penelitian. Uji coba instrumen hasil belajar IPA dilakukan pada siswa kelas VI di Gugus III, yaitu siswa SD Negeri 2 Sawan, SD Negeri 3 Sawan, dan SD Negeri 3 Menyali yang berjumlah 62 siswa. Selanjutnya dilakukan 
uji validitas yang terdiri atas uji validitas isi dan uji validitas butir, uji reliabilitas, uji daya beda, serta uji tingkat kesukaran. Dari 40 butir tes hasil belajar yang disiapkan dipilih 30 butir yang digunakan dalam penelitian.

Data hasil penelitian yang diperoleh dianalisis menggunakan analisis statistik deskriptif dan inferensial. Analisis statistik deskriptif yang dilakukan yaitu, mencari gejala pusat (mean, median, dan modus) dan variabilitas (standar deviasi dan varians). Rata-rata hitung yang diperoleh kemudian dikategorikan berdasarkan skala lima. Analisis statistik inferensial atau uji prasyarat yang harus dilakukan yaitu, (1) uji normalitas sebaran data dilakukan untuk mengetahui data motivasi berprestasi dan hasil belajar IPA berdistribusi normal atau tidak, (2) uji homogenitas varians dilakukan untuk mengetahui data motivasi berprestasi dan hasil belajar IPA dari dua kelompok memiliki tingkat kemampuan yang sama atau tidak, dan (3) uji linieritas hubungan dilakukan untuk mengetahui hubungan antara motivas berprestasi dan hasil belajar IPA bersifat linier atau tidak. Uji prasyarat dilakukan dengan bantuan SPSS versi 21. for windows.

\section{Hasil dan Pembahasan}

Rangkuman deskripsi data hasil belajar IPA pada kelompok eksperimen dan kontrol dapat dilihat pada Tabel 1.

Tabel 1. Rangkuman Deskripsi Data Hasil Belajar IPA

\begin{tabular}{lll}
\hline Statistik Deskriptif & $\begin{array}{l}\text { Hasil Belajar IPA } \\
\text { Kelompok Eksperimen }\end{array}$ & Kelompok Kontrol \\
\hline Mean & 22,47 & 16,00 \\
Median & 22,75 & 15,55 \\
Modus & 22,90 & 15,01 \\
Varians & 13,17 & 16,98 \\
Standar Deviasi & 3,63 & 4,12 \\
Skor Maksimun & 29 & 24 \\
Skor Minimum & 13 & 9 \\
Rentangan & 17 & 16 \\
\hline
\end{tabular}

Berdasarkan hasil analisis statistik deskriptif pada Tabel 1, skor rata-rata hasil belajar pada kelompok eksperimen sebesar 22,47 berada pada kategori tinggi. Hasil belajar IPA pada kelompok kontrol menunjukkan bahwa skor rata-rata sebesar 16,00 berada pada kategori sedang. Jadi skor rata-rata pada kelompok eskperimen lebih besar dibandingkan skor rata-rata pada kelompok kontrol. Pada kelompok eksperimen sebagian skor siswa cenderung tinggi, dapat dilihat pada gambar hasil belajar IPA kelompok eksperimen yang disajikan dalam bentuk histogram pada Gambar 1.

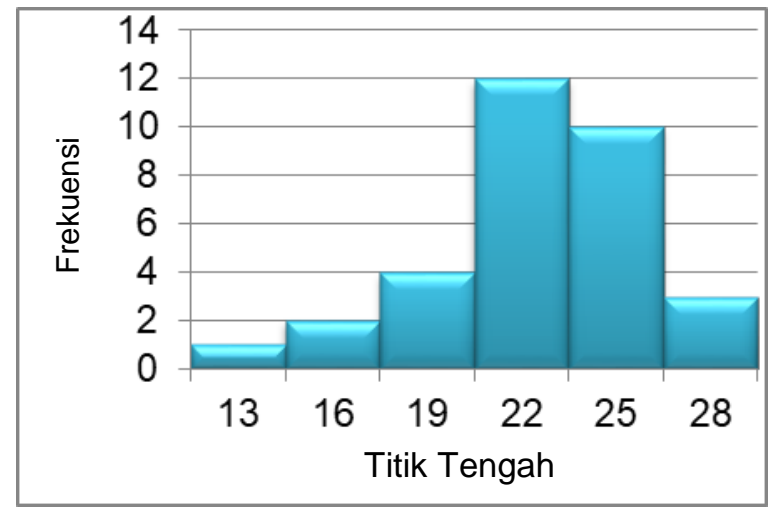

Gambar 1. Histogram Data Hasil Belajar Kelompok Eksperimen 
Pada kelompok kontrol sebagian skor hasil belajar IPA siswa cenderung rendah, dapat dilihat pada gambar hasil belajar IPA kelompok eksperimen yang disajikan dalam bentuk histogram pada Gambar 2.

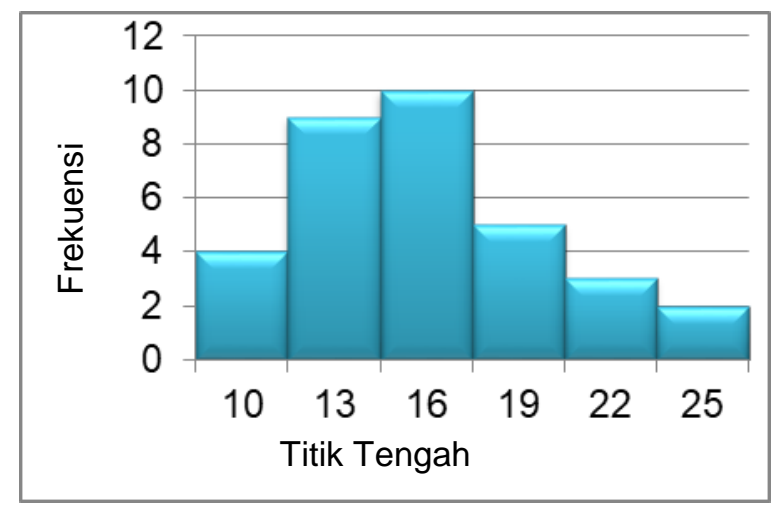

Gambar 2. Histogram Data Hasil Belajar Kelompok Kontrol

Hasil uji prasyarat menunjukkan data berdistribusi normal, memiliki variansi homogen, dan data motivasi berprestasi dengan hasil belajar IPA memiliki hubungan yang linier. Merujuk pada hasil uji prasyarat tersebut, uji hipotesis pertama dan hipotesis kedua dapat dilakukan. Hasil uji hipotesis pertama menggunakan uji-t sampel independent menunjukkan nilai $t_{\text {hitung }}=6,583$ dengan nilai signifikansi $0,000<0,05$ maka $\mathrm{H}_{0}$ ditolak dan $\mathrm{H}_{1}$ diterima. Jadi terdapat perbedaan yang signifikan hasil belajar IPA siswa yang dibelajarkan dengan model pembelajaran kolaboratif dan siswa yang dibelajarkan dengan pembelajaran konvensional. Hasil uji hipotesis kedua menggunakan ANAKOVA satu jalur menunjukkan nilai $\mathrm{F}_{\text {hitung }}=76,791$ dengan nilai signifikansi $0,000<0,05$ maka $\mathrm{H}_{0}$ ditolak dan $\mathrm{H}_{1}$ diterima. Jadi terdapat perbedaan yang signifikan hasil belajar IPA siswa yang dibelajarkan dengan model pembelajaran kolaboratif dan siswa yang dibelajarkan dengan pembelajaran konvensional setelah mengontrol motivasi berprestasi siswa. Uji hipotesis dilakukan dengan bantuan SPSS versi 21. for windows.

\section{Sebelum Mengontrol Motivasi Berprestasi Siswa}

Berdasarkan deskripsi data hasil penelitian, rata-rata hasil belajar IPA kelompok eksperimen lebih besar dibandingkan rata-rata hasil belajar IPA kelompok kontrol. Dilihat dari hasil pengujian hipotesis pertama diperoleh nilai signifikansi lebih kecil dari 0,05 . Jadi dapat disimpulkan terdapat perbedaan yang signifikan hasil belajar IPA siswa yang dibelajarkan dengan model pembelajaran kolaboratif dan hasil belajar IPA siswa yang dibelajarkan dengan pembelajaran konvensional pada siswa kelas V SD di Gugus III Kecamatan Sawan Kabupaten Buleleng Tahun Pelajaran 2017/2018. Model pembelajaran kolaboratif memiliki lima fase utama, setiap fase yang dilalui mampu memberikan perubahan positif bagi siswa dan guru.

Fase pertama yaitu orientasi siswa. Pada fase ini guru menuntun siswa menggali pengetahuan yang dimiliki dengan cara-cara yang menarik dalam pemberian apersepsi. Temuan pada penelitian ini yaitu, siswa menjadi fokus dalam mengikuti pembelajaran karena apersepsi yang diberikan sangat menarik. Benda-benda nyata yang dekat dengan kehidupan siswa digunakan dalam apersepsi, misalnya pada materi pembiasan cahaya guru melakukan apersepsi dengan membawa aquarium berbentuk bulat dengan satu ikan mas di dalamnya. Siswa sangat antusias melihat aquarium tersebut, kesempatan ini dimanfaatkan oleh guru dengan mengajukan beberapa pertanyaan, seperti "bagaimana tampak ikan pada aquarium dari tempat duduk anak-anak?" dan "mengapa ikan terlihat lebih besar dari kenyataannya jika dilihat dari tempat duduk anak'-anak?". Pertanyaan yang diajukan guru mengarahkan siswa pada pembelajaran yang akan dilaksanakan, sehingga pada akhirnya siswa mampu terfokus pada kegiatan pembelajaran. Hal tersebut senada dengan pendapat yang 
dikemukakan oleh Deporter (2010) yang menyatakan untuk menghilangkan rasa takut dan pikiran negatif selama kegiatan pembelajaran, maka pembelajaran harus dimulai dengan pikiran yang fokus dan percaya diri.

Kedua, siswa melakukan pembentukkan kelompok. Pada fase ini guru menuntun siswa untuk membentuk kelompok kecil yang terdiri atas maksimal 4 orang dengan jenis kelamin dan kemampuan yang heterogen. Temuan pada penelitian ini yaitu, siswa yang awalnya bekerja dengan tidak maksimal karena pembentukkan kelompok yang tidak beraturan, saat ini sudah mampu bekerja dengan maksimal dan komunikasi lebih interaktif karena siswa memiliki kemampuan yang berbeda sehingga informasi yang diperoleh menjadi beragam. Pembentukkan kelompok dilakukan dengan sistem undian yang telah disiapkan oleh guru, selanjutnya siswa mengambil undian tersebut secara bergantian. Empat siswa yang mendapatkan undian nomor 1 secara otomatis menjadi kelompok satu dan begitu seterusnya, sehingga terbentuk delapan kelompok heterogen. Selanjutnya, siswa dituntun untuk mengatur meja dan kursi seperti huruf $U$ pada awal pembelajaran saja dan akan digunakan seterusnya. Hal tersebut senada dengan pendapat yang dikemukakan oleh Sato (2014) yang menyatakan alasan pencampuran laki-laki dan perempuan pada proses pembentukkan kelompok membuat siswa lebih aktif dalam proses eksplorasi karena komunikasi yang terjadi lebih interaktif. Posisi tempat duduk seperti huruf $U$ membuat pembelajaran menjadi kondusif karena informasi yang disampaikan dapat didengar dengan baik oleh siswa dan guru.

Ketiga, guru menuntun siswa dalam fase penyusunan tugas pembelajaran. Pada fase ini, terjadi kegiatan eksplorasi yang dilakukan siswa melalui percobaan. Temuan pada penelitian ini yaitu, siswa sangat antusias dalam melakukan percobaan untuk menemukan suatu konsep, misalnya pada materi pembiasan cahaya, siswa mencoba meletakkan pensil di dalam gelas bening berisi air. Ternyata dilihat dari luar, pensil tersebut bengkok namun kenyataannya pensil tersebut tidak bengkok. Siswa bersama kelompok mulai melakukan pencatatan hasil temuan pada lembar kerja sehingga dapat menarik simpulan. Akhirnya siswa menemukan konsep baru dengan percobaan tersebut. Selama proses eksplorasi berlangsung siswa selalu membutuhkan bantuan orang lain baik siswa lain dalam satu kelompok, siswa lain yang berbeda kelompok, dan guru untuk memecahkan permasalahan yang dialami, sehingga siswa saling bergantung secara positif melalui komunikasi yang efektif, menyenangkan, dan tidak monoton. Hal tersebut didukung oleh teori Zone of Proximal Development (ZPD) oleh Vygotsky (dalam Barkley, dkk, 2014) yang menyatakan $Z P D$ adalah zona yang berhubungan dengan tingkat perkembangan, pada awalnya individu mampu menyelesaikan masalah yang dialami sendiri, namun seiring perkembangannya individu membutuhkan bimbingan teman sebaya, guru atau orang tua untuk menyelesaikan permasalahan yang dihadapi. Didukung juga oleh hasil penelitian yang dilakukan Primadiati dan Djukri (2017) yang menyatakan model collaborative learning terbukti lebih efektif menginduksi perkembangan kognitif siswa, karena pada situasi belajar kolaboratif ada unsur ketergantungan positif untuk mencapai kesuksesan.

Keempat, guru memfasilitasi kolaborasi siswa pada pengerjaan soal sharing dan jumping. Soal sharing adalah soal yang berada pada level buku pelajaran dan soal jumping berada pada level di luar buku pelajaran. Temuan pada penelitian ini yaitu, siswa dalam satu kelompok yang awalnya ragu-ragu sudah mulai berani bertanya dan memberikan informasi. Jika siswa dalam satu kelompok menemukan kesulitan maka siswa bertanya pada kelompok lain, dan kelompok lain harus memberikan informasi yang diketahui. Pemberian soal sharing dan jumping dilakukan secara bertahap, misalnya soal sharing untuk materi pembiasaan cahaya berkaitan dengan percobaan yang dilakukan kemudian soal tersebut dibahas secara bersama-sama. Dilanjutkan pemberian soal jumping juga berkaitan dengan materi pembiasan cahaya namun lebih dikembangkan dengan pertanyaan "mengapa hal tersebut bisa terjadi?" sehingga siswa merasa tertantang untuk menyelesaikan soal jumping. Hal tersebut didukung oleh hasil penelitian yang dilakukan Marhamah, dkk (2017) yang menyatakan hal penting dalam pembelajaran kolaboratif adalah bagaimana membuat siswa fokus sehingga hasil belajar siswa dapat meningkat, bisa diwujudkan dengan pemberian sharing task dan jumping task secara bertahap. 
Kelima, fase penilaian dan evaluasi pada tugas yang telah diselesaikan siswa. Temuan pada penelitian ini yaitu, siswa yang awalnya hanya bergantung pada anggota kelompok yang mampu saja sudah mulai belajar untuk mempertanggungjawabkan tugas yang dikerjakan secara pribadi. Selanjutnya, setiap siswa menjadi siap dalam mengemukakan apa yang telah dikerjakan karena guru juga menerapkan sistem tunjuk untuk menyampaikan hasil diskusi. Pada proses mengemukakan pendapat, guru sebelumnya sudah mencari tahu pendapat-pendapat siswa yang berbeda. Dengan sistem tunjuk guru mengajak siswa yang memiliki pendapat berbeda untuk mengemukakan pendapatnya, sehingga dari perbedaan tersebut akan ditarik suatu simpulan.

Kendala selama proses pembelajaran berlangsung adalah diskusi yang terjadi membutuhkan waktu yang cukup banyak. Kendala ini dapat diatasi dengan menyatukan beberapa kegiatan yang cocok, misalnya kegiatan eksplorasi disatukan dengan pemberian soal sharing sehingga kegiatan pembahasan dapat dilakukan sekali. Dengan tidak menghilangkan setiap tahapan yang ada pada model pembelajaran kolaboratif.

\section{Setelah Mengontrol Motivasi Berprestasi Siswa}

Berdasarkan hasil uji hipotesis kedua nilai signifikansi lebih kecil dari 0,05 sehingga terdapat perbedaan yang signifikan hasil belajar IPA antara siswa yang dibelajarkan dengan model pembelajaran kolaboratif dan siswa yang dibelajarkan dengan pembelajaran konvensional setelah mengontrol motivasi berprestasi pada siswa kelas V SD di Gugus III Kecamatan Sawan Kabupaten Buleleng Tahun Pelajaran 2017/2018. Telah dibuktikan bahwa model pembelajaran kolaboratif memengaruhi hasil belajar IPA siswa meskipun variabel motivasi berprestasi dikontrol. Kemampuan guru merancang pembelajaran dengan menerapkan model pembelajaran tertentu yang sesuai permasalahan dan karakteristik siswa sangat berpengaruh terhadap hasil belajar IPA siswa.

Terdapat banyak faktor lain baik dari luar dan dalam diri siswa yang memengaruhi hasil belajar. Djaali (2008:110) menyatakan "motivasi berprestasi merupakan salah satu faktor yang ikut menentukan keberhasilan dalam belajar". Tinggi rendahnya motivasi berprestasi yang dimiliki siswa juga harus diperhatikan. Suarni (2004) menggolongkan lima ciri-ciri umum motivasi berprestasi, sebagai berikut: (1) berupaya mencapai keberhasilan artinya usaha mencapai keberhasilan mengacu pada kegiatan-kegiatan yang dilakukan untuk memeroleh prestasi, (2) beorientasi pada keberhasilan artinya sikap sensitivitas terhadap tanda-tanda yang berkaitan dengan peningkatan prestasi, (3) inovatif dapat diartikan sebagai keinginan untuk menemukan sesuatu dengan cara yang lebih efisien, (4) bertanggungjawab artinya berupaya sempurna dalam menyelesaikan tugas, percaya diri, dan tangguh, (5) mengantisipasi kegagalan berkaitan dengan kemampuan seseorang dalam mengantisipasi kegagalan.

Siswa yang dibelajarkan dengan model pembelajaran kolaboratif pada kelompok eksperimen dengan mengontrol motivasi berprestasi mampu menciptakan pembelajaran yang efektif dengan sistem kelompok, pembelajaran yang menyenangkan karena berbagai kegiatan yang dilakukan, pembelajaran yang interaktif baik antara siswa dengan siswa dalam satu kelompok, siswa dengan siswa yang berbeda kelompok, dan siswa dengan guru. Siswa dilatih bertanya, memberikan pendapat atau informasi, dan mempertanggungjawabkan apa yang telah dikerjakan. Guru berperan sebagai fasilitator, mediator, dan motivator. Siswa yang dibelajarkan dengan pembelajaran konvensional atau tidak dengan model pembelajaran kolaboratif dengan mengontrol motivasi berprestasi siswa menunjukkan kurang adanya interaksi dalam pembelajaran, penggunaan sistem kelompok kurang efektif karena jumlah kelompok yang besar dan berbeda-beda, siswa dengan kemampuan sama berkumpul dalam satu kelompok, sehingga hanya satu atau dua orang dalam kelompok yang bersungguh-sungguh dalam mengerjakan tugas. Siswa yang mengalami kesulitan masih ragu bertanya pada siswa yang mampu dan hanya mendapatkan konfirmasi dari guru. Pada akhirnya pembelajaran dan hasil belajar IPA menjadi kurang maksimal.

Pendapat tersebut didukung oleh penelitian yang dilakukan Wahida (2016) yang menyatakan siswa dengan motivasi berprestasi tinggi akan bersemangat untuk 
melaksanakan pembelajaran di kelas sehingga hasil belajar antara siswa yang memiliki motivasi tinggi dan rendah akan berbeda. Berdasarkan paparan tersebut dapat disimpulkan bahwa setelah motivasi berprestasi dikontrol, hasil belajar IPA siswa yang dibelajarkan dengan model pembelajaran kolaboratif lebih baik dibandingkan hasil belajar IPA siswa yang dibelajarkan dengan pembelajaran konvesional..

\section{Simpulan dan Saran}

Berdasarkan hasil penelitian dan pembahasan, dapat disimpulkan penelitian ini sebagai berikut. (1) Terdapat perbedaan yang signifikan hasil belajar IPA antara siswa yang dibelajarkan dengan model pembelajaran kolaboratif dan siswa yang dibelajarkan dengan pembelajaran konvensional pada siswa kelas V SD di Gugus III Kecamatan Sawan Kabupaten Buleleng Tahun Pelajaran 2017/2018. Simpulan tersebut diperoleh dari hasil uji hipotesis pertama menggunakan uji-t sampel independent. Diperoleh rata-rata skor hasil belajar IPA siswa yang dibelajarkan dengan model pembelajaran kolaboratif lebih besar dibandingkan rata-rata skor hasil belajar IPA siswa yang dibelajarkan dengan pembelajaran konvensional $(22,47>16,00)$. (2) Terdapat perbedaan yang signifikan hasil belajar IPA antara siswa yang dibelajarkan dengan model pembelajaran kolaboratif dan siswa yang dibelajarkan dengan pembelajaran konvensional setelah mengontrol motivasi berprestasi pada siswa kelas V SD di Gugus III Kecamatan Sawan Kabupaten Buleleng Tahun Pelajaran 2017/2018.

Saran yang dapat disampaikan berdasarkan penelitian yang telah dilakukan, sebagai berikut. (1) Siswa dalam mengikuti proses pembelajaran diharapkan lebih aktif melakukan interaksi dengan teman di kelas baik dalam kelompok kecil atau klasikal. Siswa yang sudah menguasi materi diharapkan membagi informasi yang dimiliki dengan siswa lain dan siswa yang belum menguasai materi diharapkan bertanya pada siswa lain yang dianggap mampu, sehingga kolaborasi dalam bentuk hubungan saling belajar dapat terjadi. Informasi tidak hanya bersumber dari guru tetapi juga dari siswa. Siswa juga diharapkan belajar saling mendengarkan, sehingga lebih banyak informasi yang dapat dipahami. Pada saat mengerjakan soal sharing atau jumping siswa diharapkan menjawab berdasarkan apa yang dianggap benar walaupun jawaban tersebut berbeda dengan anggota kelompok lain, siswa tidak boleh memaksakan pendapat pribadi kepada orang lain karena yang dalam model pembelajaran kolaboratif mengutamakan kerja bersama walaupun hasil akhirnya berbedabeda. (2) Guru diharapkan terus mencoba atau lebih sering menggunakan model pembelajaran kolaboratif dalam mata pelajaran IPA atau digunakan juga untuk mata pelajaran lain yang dirasa cocok sehingga hasil yang dicapai semakin baik. Soal sharing dan jumping yang diberikan kepada siswa dalam setiap tahapan model pembelajaran kolaboratif diharapkan benar-benar sesuai dengan materi pada saat itu dan disesuaikan dengan levelnya, soal sharing berada pada level buku pelajaran dan soal jumping berada pada level di luar buku pelajaran. Selain itu guru juga diharapkan lebih maksimal dalam memfasilitasi kolaborasi siswa. Menghubungkan siswa yang bertanya dengan siswa yang sudah tahu, mengatasi perbedaan pendapat yang terjadi, dan membimbing siswa untuk memiliki ide atau gagasan masing-masing. Faktor-faktor lain yang memengaruhi hasil belajar juga hendaknya diperhatikan sehingga dapat dijadikan bahan pertimbangan bagi guru. (3) Kepala sekolah hendaknya melakukan kegiatan pelatihan kepada guru lain agar semua guru mengetahui tentang model pembelajaran kolaboratif sehingga dapat diterapkan di semua kelas pada mata pelajaran IPA atau mata pelajaran lainnya dan manfaat dari model pembelajaran kolaboratif dapat dirasakan oleh semua warga sekolah. (4) Peneliti lain yang berminat mengadakan penelitian lebih lanjut tentang model pembelajaran kolaboratif diharapkan menambah variabel-variabel yang akan diteliti baik variabel terikat, variabel kontrol ataupun variabel moderator dan dapat melaksanakan penelitian untuk mata pelajaran selain IPA. 


\section{Daftar Pustaka}

Barkley, Elizabert., dkk. 2014. Teknik-Teknik Pembelajaran Kolaboratif. Terjemahan Narulita Yusron. Collaborative Learning Techniques. 2005. Bandung: Nusamedia.

Deporter, dkk. 2010. Mempraktikann Quantum Learning di Ruang-ruang Kelas. Bandung: Kaifa.

Dewi, Mia Rossmalisa., dkk. 2016. "Pengaruh Model Pembelajaran Kolaboratif berbasis Lesson Study Terhadap Kemampuan Berpikir Kritis Siswa”. Jurnal Edukasi UNEJ, Volume 3, Nomor 2 (hlm. 29-33).

Djaali. 2008. Psikologi Pendidikan. Jakarta: Bumi Aksara.

Firmansyah, Helmy. 2009. "Hubungan Motivasi Berprestasi Siswa dengan Hasil Belajar Pendidikan Jasmani”. Jurnal Pendidikan, Volume 6, Nomor 1 (hlm. 30-33).

Kosasih, Nandang dan Dede Sumarna. 2013. Pembelajaran Quantum dan Optimalisasi Kecerdasan. Bandung: Alfabeta.

Marhamah, dkk. 2017. "Pengaruh Model Pembelajaran Kolaboratif Berbasis Lesson Study Learning Community (LSLC)". Jurnal IImiah Mahasiswa (JIM) Pendidikan Fisika, Volume 2, Nomor 3 (hlm. 277-282).

Musfiqon. 2012. Pengembangan Media dan Sumber Pembelajaran. Jakarta: Prestasi Pustaka Karya.

Office for Professional Development. 2006. Bloom's Taxonomy "Revised" Key Word, Model Question, and Intructional Strategies. USA: Indiana University. Tersedia pada www.center.iupui.edu/ctl/idd/does/ Bloomrevised.doc. (diakses tanggal 18 Januari 2017).

Primadiati, Ika Dewi dan Djukri. 2017. "Pengaruh Model Collaborative Learning terhadap Peningkatan Motivasi dan Hasil Belajar IPA Siswa Kleas IV SD". Jurnal Prima Edukasia, Volume 5, Nomor 1, ISSN 2460-9927 (hlm 47-57).

Samatowa, Usman. 2010. Pembelajaran IPA di Sekolah Dasar. Tanggerang Selatan: Universitas Terbuka.

Santoso, Singgih. 2013. "Pengaruh Model Pembelajaran Kolaboratif dan Motivasi Belajar Terhadap Peningkatan Hasil Belajar Fisika Kelas X SMA Negeri 1 Purwantoro Wonogiri, Jawa Tengah". Berkala Fisika Indonesia. Volume 5 Nomor 1 (hlm. 1519).

Saputra, Henry Januar., dkk. 2017. "Keefektifan Pembelajaran IPA Menggunakan Model Complette Sentence Berbantuan Card Terhadap Hasil Belajar Siswa Kelas III SDN Ngelowetan Kabupaten Demak". Jurnal IImiah Sekolah Dasar,Volume 1, Nomor 3 (hlm. 171-178).

Sato, Manabu. 2014. Mereformasi Sekolah Konsep dan Praktek Komunitas Belajar. Tokyo: Iwanami Shoten Publishers.

Sofyan. 2014. Psikologi Pendidikan. Bandung: Alfabeta.

Suarni, Ni Ketut. 2004. Meningkatkan Motivasi Berprestasi Siswa Sekolah Menengah Umum di Bali dengan Strategi Pengelolaan Diri Model Yates. Disertasi Yogyakarta. PPS UGM Yogyakarta. 
Sudarman. 2008. "Penerapan Metode Collaborative Learning untuk Meningkatkan Pemahaman Materi Mata Kuliah Metodologi Penelitian”. Jurnal Pendidikan Inovatif , Volume 3, Nomor 2 (hlm. 94-100).

Susanto, Ahmad. 2013. Teori Belajar dan Pembelajaran di Sekolah Dasar. Jakarta: Kencana Prenada Media Group.

Syaefudin, Udin. 2009. Perencanaan Pendidikan. Bandung: Remaja Rosdakarya.

Undang-Undang Republik Indonesia Nomor 20 Tahun 2003 tentang Sistem Pendidikan Nasional. Jakarta: Depdiknas.

Wahida, Miftahur. 2014. "Pengaruh Model Pembelajaran Inkuiri Terbimbing dan Motivasi Berprestasi Terhadap Hasil Belajar IPA Siswa Kelas V SD Di Kelurahan Kaliuntu Tahun Pelajaran 2015/2016". Mimbar PGSD Unniversitas Pendidikan Ganesha. Volume 4, Nomor 1 (hlm. 1-11). 